\title{
An assessment of the laboratory tests used to monitor the exposure of lead workers
}

\author{
BIRGITTA HAEGER-ARONSEN \\ Department of Medicine, Malmö, University of Lund, Sweden
}

\begin{abstract}
Hæger-Aronsen, Birgitta (1971). Brit. J. industr. Med., 28, 52-58. An assessment of the laboratory tests used to monitor the exposure of lead workers. In order to ascertain which laboratory tests are valuable for the monitoring of lead workers, 168 men exposed to lead at eight factories were examined for lead $(\mathrm{Pb})$, protoporphyrin $(\mathrm{PP})$, haemoglobin $(\mathrm{Hb})$, and basophilic stippling of red cells (BSC) in the blood and for $\delta$-aminolevulinic acid (ALA) and coproporphyrin $(\mathrm{CP})$ in the urine.

The counting of BSC and the determination of PP in the blood are both complicated and time-consuming procedures. As they do not offer any particular advantages in the detection or evaluation of lead poisoning they are considered as less suitable.

The concentration of $\mathrm{Pb}$ in the blood reflects the absorption of the lead but not its effect. This is certainly a disadvantage.

A highly significant, negative correlation was found between $\mathrm{Hb}$ in the blood and ALA in the urine.

The concentrations of ALA and CP in the urine are both good indicators of the degree of lead poisoning. The former is more specific and more sensitive and is therefore considered the most suitable test for the biochemical monitoring of lead workers. A simple, safe, and quick method is recommended.

Determinations of $\mathrm{Hb}$ and $\mathrm{Pb}$ in the blood may be useful as supplementary methods in the evaluation of lead poisoning but are, in our experience, only seldom needed.
\end{abstract}

It has been known since antiquity that lead poisoning may occur when the metal gains access to the body tissues by inhalation, ingestion, or skin contact. The first descriptions of the clinical picture of such intoxication date back to the middle of the seventeenth century (Stockhausen, 1656), but it was not until two centuries later that anaemia was recognized as an integral part of the condition (Laennec, 1831).

The pathogenesis of the anaemia is not properly understood. However, owing to the effect of lead on various enzymes catalysing glycolysis and certain steps in the synthesis of haem, retarded maturation of the red cells and haemoglobin deficiency must be important features (Waldron, 1966).

Haemolysis which is prominent in acute lead poisoning in man (Leikin and Eng, 1963) is believed to be due to the toxic effect of the metal on the red cell membranes, resulting in cellular fragility (Teisinger, Zumanová, and Zezula, 1958; Prankerd, 1961). Transient jaundice (Karlog and Møller, 1958; Crutcher, 1963) and increased excretion of urobilinogen in the faeces (Baikie, 1954) and urine (Simpson, Seaton, and Adams, 1964) have been taken as evidence of the anaemia being of haemolytic type. Coombs test is usually negative (Sutherland and Eisentraut, 1956), but it is sometimes positive in patients with reticulocytosis and/or severe punctate basophilia (Crutcher, 1963). This is believed to be due to the tendency of these cells to retain globulin, possible transferrin, on their membranes (Jandl, 1960).

Punctate basophilia has long been known to occur in lead poisoning (Behrend, 1899). It is due to the action of the lead on the young cells in the bone 
marrow with consequent alteration and aggregation of the ribosomes (Jensen and Moreno, 1964; Jensen, Moreno, and Bessis, 1965). Other examples of the effect of lead on the morphology of red cells are polyploidy (Beritić and Vandekar, 1956) and abnormal mitoses of the nuclei of erythroblasts (Rondanelli, Gorini, Colombi, and Verga, 1958).

The multiple effect of lead on synthesis of haem is well documented and has been described in detail elsewhere (Hæger-Aronsen,' 1960). Partial blockage of $\delta$-aminolevulinic acid (ALA) dehydrase (Gibson, Neuberger, and Scott, 1955; Nakao, Wada, and Yano, 1968), coproporphyrinogenase (Rubino, 1962), and haemsynthetase (Rimington, 1951; Goldberg, Ashenbrucker, Cartwright, and Wintrobe, 1956; Jandl, Inman, Simmons, and Allen, 1959) has been demonstrated in experimental animals and in man. This impaired synthesis can probably explain most of the increase in the concentration of ALA and coproporphyrin (CP) in the urine (Rubino, 1962; Gajdos and Gajdos-Török, 1969) and of protoporphyrin (PP) in the red cells (Lichtman and Feldman, 1963).

Sano (1958) felt that acceleration of the synthesis of haem was necessary for the concentrations of porphyrins and precursors to reach the high levels occurring in lead poisoning. But the activity of ALA synthetase, the rate-limiting enzyme in the synthetizing process (Granick and Urata, 1963), proved normal in lead-poisoned rabbits (Gajdos and Gajdos-Török, 1969; Gibson and Goldberg, 1970). In acute intermittent porphyria, an inborn error of metabolism with defective porphyrin synthesis, which both clinically and biochemically resembles lead poisoning (Waldenström, 1937; Dagg, Goldberg, Lochhead, and Smith, 1965), the ALA synthetase activity has been found to be markedly raised and this rise has been regarded as an explanation of the increased excretion of porphyrin precursors (Tschudy, Perlroth, Marver, Collins, Hunter, and Rechcigl, 1965; Masuya, 1969).

Characteristics of the anaemia in lead poisoning are mild hypochromia, increased serum iron, slightly reduced survival time of the red blood cells, and abundance of sideroblasts. It has been classed as a type of sideroblastic anaemia (Mollin, 1965).

In view of the range of analytical data available, we thought it worth while to try to find out which laboratory tests are valuable for the monitoring of lead workers.

By lead poisoning was meant lead absorption sufficiently great to cause characteristic changes in the blood and urine, even if there are no clinical symptoms.

Material

The samples were collected at routine examination of
168 male lead workers. Of these, 78 were employed at two factories manufacturing accumulators, 72 at two factories producing plastics, 16 at three foundries using material containing lead, and 2 were occupied with the cleaning of a tank used for storage of petrol containing lead. All the workers were exposed to inorganic lead dust (mostly $\mathrm{Pb}, \mathrm{PbO}$, and $\mathrm{PbCO}_{3}$ ) except the last two who were exposed to organic (tetraethyl-) lead fumes. The two last-mentioned men had worked in the tank for only four days while all the others had been occupied with lead work for at least three months. Twenty-nine men were foreigners, mostly Jugo-Slavs. None of them was known to have any blood disease.

The blood and urine samples used in intra-individual comparisons were obtained on the same day. The blood samples examined for lead $(\mathrm{Pb})$ were collected directly in heparinized tubes by venepuncture using carefully washed needles. The samples were examined within 14 days of collection. Samples for estimation of the PP in the red cells were also obtained by venepuncture, while capillary blood was used for the counting of punctate basophils (BSC) and for the determination of haemoglobin (Hb). These three last-mentioned determinations were made on the day the samples were obtained.

Urine to be examined for ALA and CP consisted of early morning samples. These were stored at $+4^{\circ} \mathrm{C}$ in the dark from the time they were received at the laboratory until they were analysed - always within three days of voiding. No preservative was added. The $\mathrm{pH}$ was always ascertained before determination and was regularly found to be somewhat less than 7 .

\section{Methods}

Determination of $\mathrm{Pb}$ in blood was performed by $\mathrm{AB}$ Analytica, Stockholm, in a Hilger \& Watts large automatic spectrograph supplied with a quartz optical system.

Red cells were examined for free PP by the method of Wranne (1960). The punctate basophils in the peripheral blood were counted in the way previously described (Hæger-Aronsen, 1960).

$\mathrm{Hb}$ was measured as cyanmethaemoglobin. Blood was always obtained with the worker sitting.

The urine was analysed for ALA by the method of Mauzerall and Granick (1956) except the last 24 specimens, which were examined by the method of Grabecki, Haduch, and Urbanowicz, (1967). The CP content of the urine was measured by the method described previously (Hæger-Aronsen, 1960).

The results of the analyses were expressed in terms of weight per volume.

Coefficients of correlation ( $r$ ) and regression lines were calculated according to standard statistical methods. A difference was said to be almost significant, significant, and highly significant when the corresponding level of probability was 0.05 to $0.01,0.01$ to 0.001 , and less than 0.001 , respectively.

\section{Results}

The upper normal (mean +2 SD) and lower normal (mean $-2 \mathrm{SD}$ ) limits used are given in Table 1. All the values except $\mathrm{Pb}$ are from our own published results (Hæger-Aronsen, 1960, 1963). The Pb limit was taken from Kehoe (1961). 
TABLE 1

Normal Limits Used

\begin{tabular}{c|l|l}
\hline Urine & Blood & Normal limits \\
& & \\
\hline & & \\
ALA & & $\leqslant 0.57 \mathrm{mg} \%$ \\
CP & BSC & $\leqslant 15 \mu \mathrm{g} \%$ \\
& $\mathrm{Hb}$ & $\geqslant 10000 \mathrm{RBC}$ \\
& $\mathrm{Pb}$ & $\leqslant 40.2 \mathrm{~g} \% \%^{1}$ \\
& $\mathrm{PP}$ & $\leqslant 25 \mu \mathrm{g} \%$ \\
& & \\
\hline
\end{tabular}

${ }^{1}$ For men in Malmö, Sweden

The correlations found between the results of the various analytical tests are given in Table 2.

TABLE 2

Correlation between Results of Various Analytical Tests

\begin{tabular}{l|r|c|r|c}
\hline Correlation & $\mathrm{n}$ & $\mathrm{r}$ & $\mathrm{p}$ & Fig.no. \\
& & & & \\
\hline ALA/Pb1 & 110 & - & - & 1 \\
ALA/CP & 55 & +0.85 & $<0.001$ & 2 \\
ALA/Hb & 168 & -0.35 & $<0.001$ & 3 \\
ALA/BSC & 79 & +0.65 & $<0.001$ & 4 \\
PP/Pb & 38 & +0.50 & 0.01 to 0.001 & 5 \\
ALA/PP & 38 & +0.34 & 0.05 to 0.01 & 6 \\
\hline
\end{tabular}

${ }^{1}$ Curvilinear function

ALA in urine, $\mathrm{mg} / 100 \mathrm{ml}$; $\mathrm{CP}$ in urine, $\mu \mathrm{g} / 100 \mathrm{ml} ; \mathrm{Pb}$ in blood, $\mu \mathrm{g} / 100 \mathrm{ml}$; $\mathrm{Hb}$ in blood, $\mathrm{g} / 100 \mathrm{ml}$; BSC in blood, number per 10000 red cells; $P P$ in red blood cells, $\mu \mathrm{g} / 100 \mathrm{ml}$.

\section{Discussion}

The concentration of ALA varied closely with $\mathrm{Pb}$ (Fig. 1) and still more closely with CP (Fig. 2, Table 2). The latter is perhaps not so noteworthy, for while the $\mathrm{Pb}$ in the blood reflects only the amount of lead absorbed, the concentration of ALA and that of CP in the urine are indicators of the toxic effect of the metal. This effect is also mirrored by the concentration of $\mathrm{Hb}$, the number of punctate basophils, and the PP content of the red cells. The susceptibility to lead varies from individual to individual, and enzymes catalysing various steps in the production of haem differ from one another in their tolerance of lead depending, among other things, on whether they are bound to mitochondria (Miani and Viterbo, 1958) and whether they contain sulphydryl group(s).

Selander and Cramér (1970) pointed out that the

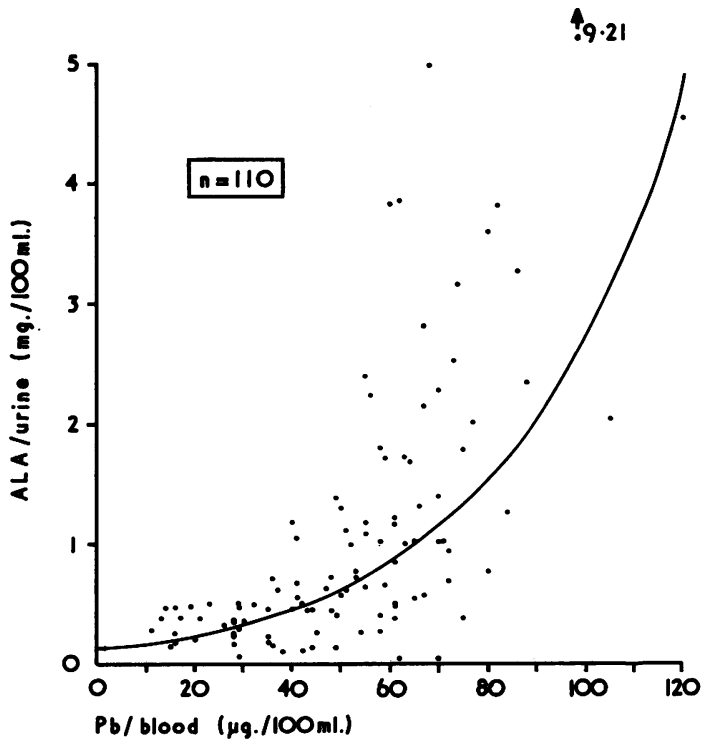

FIG. 1. Correlation between concentrations of ALA in urine and $\mathrm{Pb}$ in blood from lead workers. The relationship was found to be curvilinear (ALA $=10^{0.01294 P b-}$ 0.8605).

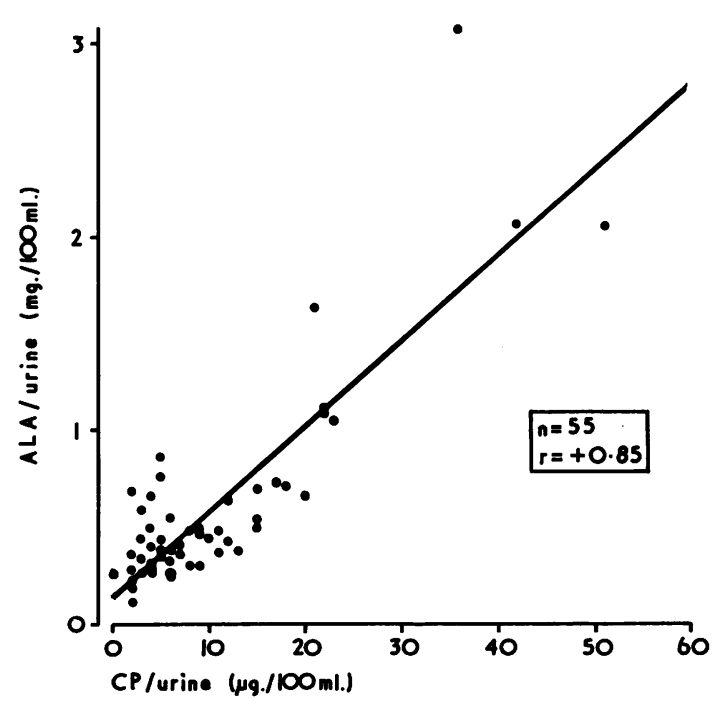

FIG. 2. Correlation between concentrations of ALA and $\mathrm{CP}$ in urine from lead workers. The regression line of ALA on CP is given (ALA $=0.0442 \mathrm{CP}+0.1412$ ).

regression of ALA on $\mathrm{Pb}$ in the blood is not straight but curvilinear, something we were able to confirm from our results. After logarithmic transformation of the ALA values a rectilinear regression line was obtained $(\log \mathrm{ALA}=0.01294 \mathrm{~Pb}-0.8605)$ with a 
highly significant $r$ of +0.61 . The corresponding $r$ of Selander and Cramér (1970) was $+0 \cdot 74, n=150$. Those authors stress the importance of attaching great interest to high or increasing ALA values, even if the blood $\mathrm{Pb}$ levels are not correspondingly high.

Gibson, Mackenzie, and Goldberg (1968) found no correlation between ALA in the urine and $\mathrm{Pb}$ in the blood in 100 lead workers, while Holmqvist (1970) demonstrated a rectilinear relationship $(r=+0.46)$ in a study of 1908 workers at a lead-melting plant.

Close positive correlations between ALA and CP in the urine $(r=0.92$ to 0.65$)$ have been demonstrated previously in series ranging from 12 to 100 lead workers (de Kretser and Waldron, 1963; Gattner and Schrantz, 1964; Cramér and Selander, 1965; de Bruin and Hoolboom, 1967).

A highly significant, negative correlation between ALA and $\mathrm{Hb}$ was found (Table 2). As in the 100 lead workers examined by Gibson and her colleagues (1968), this tendency was even more pronounced when the results were classified according to the concentration of $\mathrm{Hb}$ (Fig. 3).

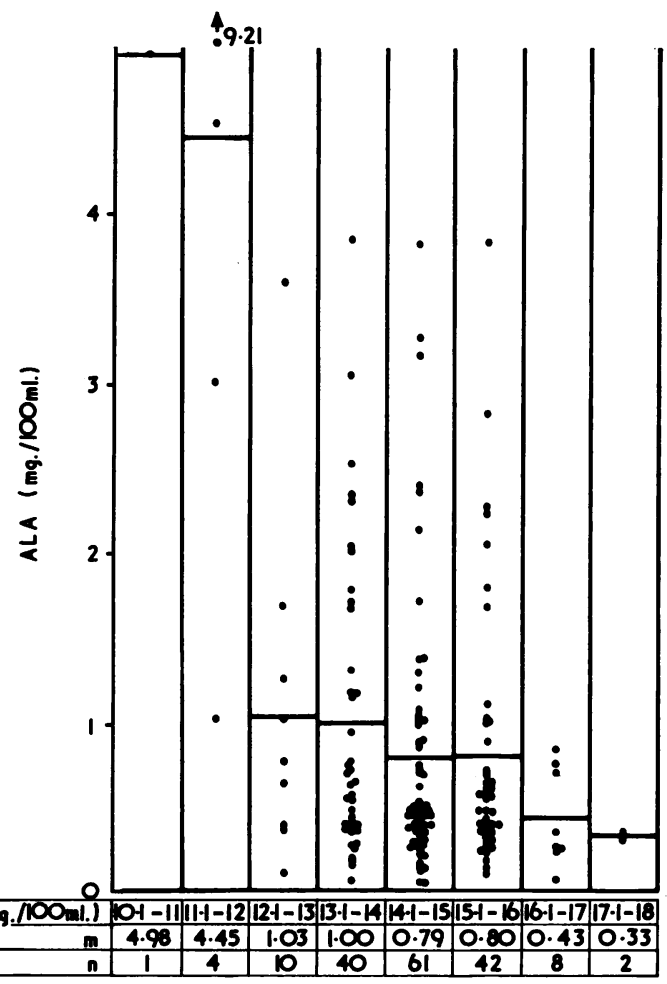

FIG. 3. Urinary excretion of ALA by lead workers $(n=168)$, divided in groups according to their Hb concentration in blood.
Williams (1966) found no correlation between the concentrations of $\mathrm{Pb}$ in the blood and $\mathrm{Hb}$ in 655 lead workers. He therefore felt that regular determination of the $\mathrm{Hb}$ in lead workers could be omitted so long as the concentration of the lead did not exceed $110 \mu \mathrm{g} / 100 \mathrm{ml}$. Our results do not support this view.

While the correlation of basophils with $\mathrm{Pb}$ in the urine has previously been shown to be significant (Hæger-Aronsen, 1960) that with the concentration of ALA in the urine is highly significant (Table 2, Fig. 4).

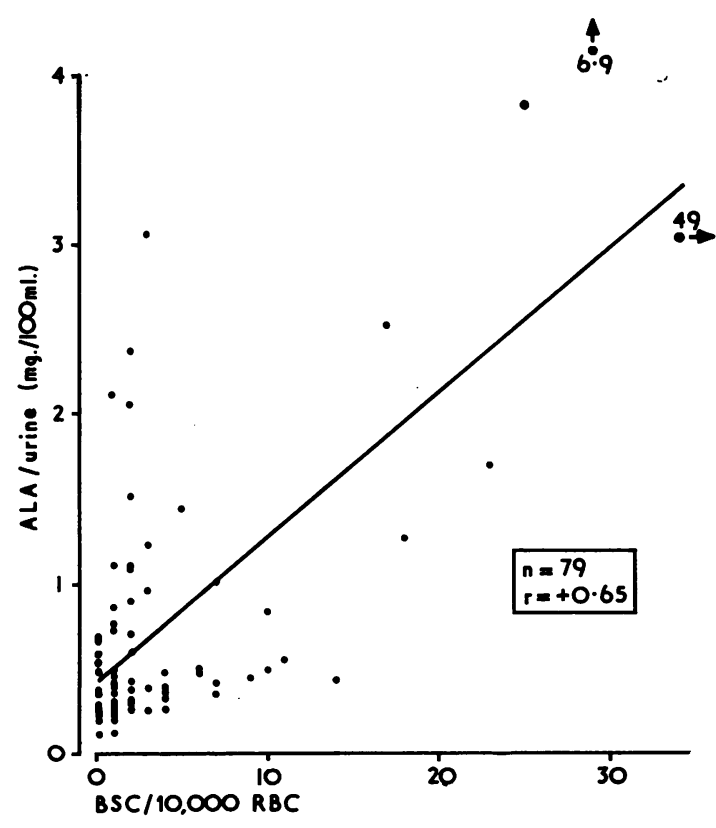

FIG. 4. Correlation between concentration of ALA in urine from lead workers and the number of BSC in blood on the same day. The regression line of ALA on BSC is given (ALA $=0.0850 \mathrm{BSC}+0.4284)$.

The concentration of PP in the red cells unexpectedly correlated more closely with that of the lead in the blood $(r=+0.50)$ than with the ALA in the urine $(r=+0 \cdot 34)$. Both series were, however, only small with 38 pairs in each (Figs. 5 and 6).

Summing up, the counting of punctate basophils and the determination of PP in the red cells are both complicated and time-consuming procedures and therefore less suitable as routine tests in the supervision of lead workers.

Determinations of the excretion of ALA and CP in the urine are both satisfactory (Hæger-Aronsen, 


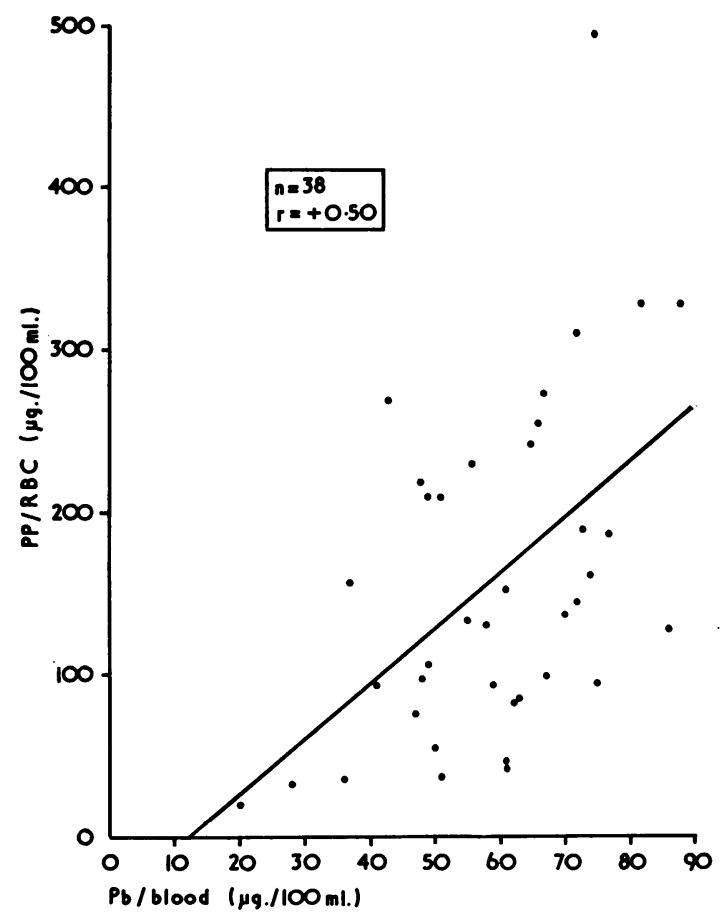

FIG. 5. Correlation between concentrations of PP in red blood cells and $\mathrm{Pb}$ in blood from lead workers. The regression line of $\mathrm{PP}$ on $\mathrm{Pb}$ is given ( $\mathrm{PP}=3.3718 \mathrm{~Pb}-41 \cdot 3030)$.

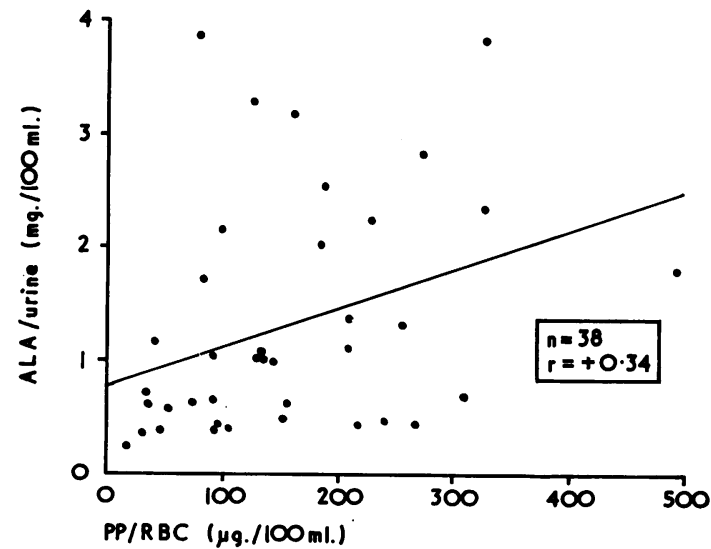

FIG. 6. Correlation of concentrations of ALA in urine and $P P$ in red blood cells from lead workers. The regression line of ALA on PP is given (ALA $=0.0034$ PP + 0.7937).

1960; Zielhuis, 1961). Increased excretion of ALA in the urine without simultaneously increased porphobilinogen has so far been observed only in porphyria cutanea tarda (Hæger, 1958; Heilmeyer and Clotten, 1960), hypochromic anaemia after gastrectomy (Danieli, Gajdos-Török, and Gajdos, 1961), and hereditary tyrosinaemia (Gentz, Johansson, Lindblad, Lindstedt, and Zetterström, 1969), while coproporphyrinuria occurs in various forms of anaemia, particularly the diffuse haemolytic type, in jaundice due to hepatocellular damage or biliary obstruction, in some infectious diseases such as pneumonia and poliomyelitis, in various types of poisoning with substances such as mercury, bismuth, and sulphonamides, and in other diseases. Further, the excretion of ALA in the urine seems to increase earlier than that of CP and is thus a more sensitive indicator of lead poisoning (Hæger-Aronsen, 1960; Balbo, Gualdi, and Marucci, 1965; Djuric, Novak, Milic, and Kalic-Filipovic, 1966; de Bruin and Hoolboom, 1967). Now that an excellent quick method is available for the determination of ALA in urine (Grabecki and his colleagues, 1967) it may be regarded as the method of choice for detecting and estimating the degree of lead poisoning in lead workers. The analysis can be performed on spot samples and the ALA content can be expressed in weight per volume (Cramér and Selander, 1967; Hæger-Aronsen, 1970).

Determinations of $\mathrm{Hb}$ and $\mathrm{Pb}$ in the blood are good supplementary indicators for estimating the degree of lead intoxication but are seldom needed in routine work.

This work was supported by a grant to J. Waldenström and B. Haeger-Aronsen from the Swedish Medical Research Council.

Thanks are due to Mrs. Ljudmila Marčič for skilful laboratory help and to assistants Tore Persson and Harald Andersson, Department of Mathematical Statistics, Lund, for valuable advice with some statistical problems.

\section{References}

Baikie, A. G. (1954). The fecal excretion of urobilinogen of normal and lead poisoned guinea pigs. Blood, 9, 461-472.

Balbo, W., Gualdi, G., and Marucci, V. (1965). Ulteriore contributo allo studio del comportamento del $\delta$-ALA sierico ed urinario in soggetti esposti all'azione tossica protratta del piombo. Folia med. (Napoli), 48, 544-556.

Behrend (1899). Ueber endoglobuläre Einschlüsse rother Blutkörperchen. Discussion on Litten, Verein für Innere Medizin, Berlin. Dtsch. med. Wschr., 25, Vereins-Beilage No 42, 254.

Beritić, T., and Vandekar, M. (1956). Some observations on the morphology of erythropoietic cells in human lead poisoning. Blood, 11, 114-122.

Cramér, K., and Selander, S. (1965). Studies in lead poisoning. Comparison between different laboratory tests. Brit. J. industr. Med., 22, 311-314. 
- H. H., and Selander, S. (1967). A comparative analysis between variation in 24-hour urinary creatinine output and 24-hour urinary volume. Clin. chim. Acta, 15, 331-335.

Crutcher, J. C. (1963). Clinical manifestations and therapy of acute lead intoxication due to the ingestion of illicitly distilled alcohol. Ann. intern. Med., 59, 707-715.

Dagg, J. H., Goldberg, A., Lochhead, A., and Smith, J. A. (1965). The relationship of lead poisoning to acute intermittent porphyria. Quart. J. Med. (N.S.), 34, 163-175.

Danieli, G., Gajdos-Török, M., and Gajdos, A. (1961). Un nouveau test biologique du saturnisme: augmentation du taux urinaire et plasmatique de l'acide delta-aminolévulinique. Path. et Biol., 9, 1481-1486.

de Bruin, A., and Hoolboom, H. (1967). Early signs of leadexposure. A comparative study of laboratory tests. Brit. J. industr. Med., 24, 203-212.

de Kretser, A. J., and Waldron, H. A. (1963). Urinary delta amino-laevulinic acid and porphobilinogen in lead-exposed workers. Brit. J. industr. Med., 20, 35-40.

Djuric, D., Novak, L., Milic, S., and Kalic-Fiiipovic, D. (1966). Delta-amino-levulinic acid as early sign of lead exposure. Med. d. Lavoro, 57, 161-166.

Gajdos, A., and Gajdos-Török, M. (1969). L'activité de l'acide $\delta$-aminolévulinique-synthétase hépatique et médullaire au cours du saturnisme expérimental du Lapin. C.R. Soc. Biol. (Paris), 163, 60-63.

Gattner, H., and Schrantz, G. (1964). Bestimmung der $\delta$ Amino-lävulinsäure-Ausscheidung im Urin zur Frühdiagnose der Bleivergiftung. Dtsch. med. Wschr., 89, 1027-1035.

Gentz, J., Johansson, S., Lindblad, B., Lindstedt, S., and Zetterström, R. (1969). Excretion of $\delta$-aminolevulinic acid in hereditary tyrosinemia. Clin. chim. Acta, 23, 257-263.

Gibson, K. D., Neuberger, A., and Scott, J. J. (1955). The purification and properties of $\delta$-aminolaevulic acid dehydrase. Biochem. J., 61, 618-629.

Gibson, Sheila, L. M., and Goldberg, A. (1970). Defects in haem synthesis in mammalian tissues in experimental lead poisoning and experimental porphyria. Clin. Sci., 38, 63-72.

—- Mackenzie, J. C., and Goldberg, A. (1968). The diagnosis of industrial lead poisoning. Brit. J. industr. Med., 25, 40-51.

Goldberg, A., Ashenbrucker, H., Cartwright, G. E., and Wintrobe, M. M. (1956). Studies on the biosynthesis of heme in vitro by avian erythrocytes. Blood, 11, 821-833.

Grabecki, J., Haduch, T., and Urbanowicz, H. (1967). Die einfachen Bestimmungsmethoden der delta-Aminolävulinsäure im Harn. Int. Arch. Gewerbepath. Gewerbehyg., 23, 226-240.

Granick, S., and Urata, G. (1963). Increase in activity of $\delta$-aminolevulinic acid synthetase in liver mitochondria induced by feeding of 3,5-dicarbethoxy-1,4-dihydrocollidine. J. biol. Chem., 238, 821-827.

Hæger, B. (1958). Urinary $\delta$-aminolaevulic acid and porphobilinogen in different types of porphyria. Lancet, 2, 606-608.

Hæger-Aronsen, B. (1960). Studies on urinary excretion of $\delta$-aminolaevulic acid and other haem precursors in lead workers and lead-intoxicated rabbits. Scand. J. clin. Lab. Invest., 12, suppl. 47.

- (1963). Erythropoietic protoporphyria. A new type of inborn error of metabolism. Amer. J. Med., 35, 450-454.

- (1970). Evaluation of two methods for measuring $\delta$-aminolaevulinic acid in urine. Scand. J. clin. Lab. Invest., 25, 19-23.

Heilmeyer, L., and Clotten, R. (1960). Die Störungen der Porphyrinsynthese bei den sideroachrestischen Anämien. Schweiz. med. Wschr., 90, 934-938.

Holmqvist, I. (1970). Personal communication

Jandl, J. H. (1960). The agglutination and sequestration of immature red cells. J. Lab. clin. Med., 55, 663-681.
_- Inman, J. K., Simmons, R. L., and Allen, D. W. (1959). Transfer of iron from serum iron-binding protein to human reticulocytes. J. clin. Invest., 38, 161-185.

Jensen, W. N., and Moreno, G. (1964). Les ribosomes et les ponctuations basophiles des erythrocytes dans l'intoxication par le plomb. C.R. Acad. Sci. (Paris), 258, 35963597.

,- , and Bessis, M. C. (1965). An electron microscopic description of basophilic stippling in red cells. Blood, 25, 933-943.

Karlog, O., and Møller, K. O. (1958). Three cases of acute lead poisoning. Analyses of organs for lead, and observations on polarographic lead determinations. Acta pharmacol. (Kbh.), 15, 8-16.

Kehoe, R. A. (1961). The Harben lectures, 1960. The metabolism of lead in man in health and disease. Lecture 1. The normal metabolism of lead. J. roy. Inst. publ. Hlth, 24, 81-96.

Laennec, R. T. H. (1831). Traité de l'Auscultation Médiate, 3rd ed, Chaudé, Paris. Cited by Waldron. (1966). Brit. J. industr. Med., 23, 83-100.

Leikin, S., and Eng, G. (1963). Erythrokinetic studies of the anemia of lead poisoning. Pediatrics, 31, 996-1002.

Lichtman, H. C., and Feldman, F. (1963). In vitro pyrrole and porphyrin synthesis in lead poisoning and iron deficiency. J. clin. Invest., 42, 830-839.

Masuya, T. (1969). Pathophysiological observations on porphyrias. Acta haemat. jap., 32, 465-514.

Mauzerall, D., and Granick, S. (1956). The occurrence and determination of $\delta$-aminolevulinic acid and porphobilinogen in urine. $J$. biol. Chem., 219, 435-446.

Miani, N., and Viterbo, B. (1958). Studio istoautoradiografico sulla localizzazione del piombo $(\mathrm{RaD})$ in vari organi di cane. $Z$. Zellforsch., 49, 188-208.

Mollin, D. L. (1965). Sideroblasts and sideroblastic anaemia. Brit. J. Haemat., 11, 41-48.

Nakao, K., Wada, O., and Yano, Y. (1968). $\delta$-Aminolevulinic acid dehydratase activity in erythrocytes for the evaluation of lead poisoning. Clin. chim. Acta, 19, 319-325.

Prankerd, T. A. J. (1961). The Red Cell, pp. 54-55. Blackwell Scientific Publications, Oxford.

Rimington, C. (1951). Preliminary investigations for a study of energy utilized by the surviving fowl erythrocyte in haem synthesis, In: Ciba Foundation Conference on Isotopes in Biochemistry, edited by G. E. W. Wolstenholme, pp. 86-89. Churchill, London.

Rondanelli, E. G., Gorini, P., Colombi, R., and Verga, L. (1958). Richerche sulla patogenesi dell'anemia saturnina. L'azione del piombo sulla mitosi eritroblastica. Haematologica, 43, 1077-1094.

Rubino, G. F. (1962). The role of lead in porphyrin metabolism. Panminerva med., 4, 340-344.

Sano, S. (1958). The effect of mitochondria on porphyrin and heme biosynthesis in red blood cells. Acta haemat. jap., 21, 337-351.

Selander, S., and Cramér, K. (1970). Interrelationships between lead in blood, lead in urine, and ALA in urine during lead work. Brit. J. industr. Med., 27, 28-39.

Simpson, J. A., Seaton, D. A., and Adams, J. F. (1964). Response to treatment with chelating agents of anaemia chronic encephalopathy, and myelopathy due to lead poisoning. J. Neurol. Neurosurg. Psychiat., 27, 536-541.

Stockhausen, S. (1656). De Lithargyri Fumo noxio morbifico, ejusque metallico frequentiori morbo vulgo dicto die Hütten-Katze. Goslar.

Sutherland, D. A., and Eisentraut, A. M. (1956). The direct Coombs test in lead poisoning. Blood, 11, 1024-1031.

Teisinger, J., Zumanová, R., and Zezula, I. (1958). Effect of edathamil calcium-disodium on the lead content of red blood cells and blood proteins. Arch. industr. Hlth, 17, 295301.

Tschudy, D. P., Perlroth, M. G., Marver, H. S. Collins, 
Annie, Hunter, G., Jr., and Rechcigl, M., Jr. (1965). Acute intermittent porphyria: the first 'overproduction disease' localized to a specific enzyme. Proc. nat. Acad. Sci. (Wash.), 53, 841-847.

Waldenström, J. (1937). Studien über Porphyrie. Acta med. scand., Suppl. 82.

Waldron, H. A. (1966). The anaemia of lead poisoning: a review. Brit. J. industr. Med., 23, 83-100.
Williams, M. K. (1966). Blood lead and haemoglobin in lead absorption. Brit. J. industr. Med., 23, 105-111.

Wranne, L. (1960). Free erythrocyte copro- and protoporphyrin. A methodological and clinical study. Acta paediat., 49, Suppl. 124.

Zielhuis, R. L. (1961). Coproporphyrinuria in groups of workers as an index of inorganic lead absorption. Brit.J. industr. Med., 18, 58-62.

Received for publication April 13, 1970. 